\title{
Somatic embryogenesis in the commercial papaya hybrid UENF/Caliman 01 relying on plantlet production from sexed adult hermaphrodite donor plants
}

\author{
DRIELLY S. GOUVEA ${ }^{1}$, KRISTHIANO CHAGAS ${ }^{2}$, JAMILE L.D. CIPRIANO ${ }^{3}$, \\ JOSÉ CARLOS LOPES ${ }^{4}$, EDILSON R. SCHMILDT ${ }^{1}$, WAGNER C. OTONI ${ }^{2}$, OMAR \\ SCHMILDT $^{1}$, CAROLINE P. DE ARAUJO ${ }^{5}$ and RODRIGO S. ALEXANDRE ${ }^{5}$
}

\author{
${ }^{1}$ Departamento de Ciências Agrárias e Biológicas, Centro Universitário Norte do Espírito Santo, Universidade \\ Federal do Espírito Santo/UFES, Rodovia BR 101 Norte, Km 60, Litorâneo, 29932-540 São Mateus, ES, Brazil \\ ${ }^{2}$ Departamento de Biologia Vegetal, Centro de Ciências Biológicas e da Saúde, Universidade Federal \\ de Viçosa, Campus Universitário, Av. Peter Henry Rolfs, s/n, 36570-900 Viçosa, MG, Brazil \\ ${ }^{3}$ Instituto Federal de Minas Gerais, Campus Sabará, Rodovia MGC 262, Km 10, s/n, Sobradinho, 34515-640 Sabará, MG, Brazil \\ ${ }^{4}$ Departamento de Agronomia, Centro de Ciências Agrárias e Engenharias/CCAE, Universidade Federal \\ do Espírito Santo/UFES, Alto Universitário, s/n, Guararema, 29500-000 Alegre, ES, Brazil \\ ${ }^{5}$ Departamento de Ciências Florestais e da Madeira, CCAE/UFES. Avenida Governador \\ Lindemberg, 316, Centro, 29550-000 Jerônimo Monteiro, ES, Brazil \\ Manuscript received on May 19, 2018; accepted for publication on June 14, 2018
}

\begin{abstract}
How to cite: GOUVEA DS, CHAGAS K, CIPRIANO JLD, LOPES JC, SCHMILDT ER, OTONI WC, SCHMILDT O, ARAUJO CP AND ALEXANDRE RS. 2019. Somatic embryogenesis in the commercial papaya hybrid UENF/ Caliman 01 relying on plantlet production from sexed adult hermaphrodite donor plants. An Acad Bras Cienc 91: e20180504. DOI 10.1590/0001-3765201920180504.
\end{abstract}

\begin{abstract}
Somatic embryogenesis from explants from hermaphrodite papaya mother plants is an alternative for the production of true-to-type plants without the need for sexing. This study aimed to analyze hormonal and osmotic inducers in different somatic embryogenesis stages in the commercial hermaphrodite hybrid papaya UENF/Caliman 01. Leaf disks from in vitro shoots originated from ex vitro hermaphrodite plants were cultured in induction medium supplemented with different concentrations of 2,4-D (6, 9, 12, 15, and $18 \mu \mathrm{M})$ and 4-CPA $(19,22,25,28$, and $31 \mu \mathrm{M})$. After 90 days, the formation of somatic embryos was verified. The 2,4-D induced the formation of light brown calli with low frequency (20\%) of somatic embryogenesis. However, 4-CPA $(25 \mu \mathrm{M})$ induced $96 \%$ of embryogenic calli, which were transferred to maturation medium $(\mathrm{MM})$ and cultured for 30 days. The MM contained ABA $(0.5 \mu \mathrm{M})$ and AC $\left(15 \mathrm{~g} \mathrm{~L}^{-1}\right)$ and produced 36.6 somatic embryos callus ${ }^{-1}$, mainly on cotyledonary stage. Cotyledonary embryos were transferred to germination medium supplemented with gibberellic acid $\left(\mathrm{GA}_{3}\right)(0.0,1.44,2.88$, and 4.32 $\mu \mathrm{M})$, and the conversion into plantlets was enhanced with $\mathrm{GA}_{3}$ at $2.88 \mu \mathrm{M}$.
\end{abstract}

Key words: abscisic acid, auxins, Carica papaya L., gibberellic acid, hermaphrodite explants, polyethylene glycol.

Correspondence to: Rodrigo Sobreira Alexandre

E-mail: rodrigosobreiraalexandre@gmail.com

ORCid: https://orcid.org/0000-0002-5248-6773 


\section{INTRODUCTION}

The culture of papaya (Carica papaya L.) is exploited by several countries, Brazil being its second largest producer and exporter, producing 1.5 million tons, in an area of 32,000 hectares, with average yield of 50 tons per hectare, second only to India, with production of five million tons. Among the main consuming countries of the fruit produced in Brazil are the United States (USA), England, Germany and Portugal (CnaBrasil 2016). Brazil generates a revenue of 47.1 million USD with exports of 33.7 thousand tons a year, in which the state of Espírito Santo ranks first, averaging 12,000 tons exported per year, in which $25 \%$ are directed to the USA (Brapex 2016).

Among the hermaphrodite papaya plants of the group Solo, the cultivars Golden and Golden THB stand out. In the group Formosa, the hybrids Tainung 01 stand out worldwide and, UENF/ Caliman 01 (Calimosa) and cv. Rubi Incaper 511 stand out in Brazil (Costa et al. 2013).

Sex determination is a crucial practice in the culture of papaya, and this technique is carried out during flowering, moment in which reproductive structures are visible. Plant sex can also be identified by means of molecular markers, a technique still not viable on a large scale basis (Abreu et al. 2015). Due to this hurdle, it has been recommended to plant three to four papaya plantlets per hole, aiming at future sex determination, leaving only one hermaphrodite plant after thinning the others. However, this practice leads to higher production costs, including the purchase of seeds - for example UENF/Caliman 01 (US\$ 3,225.00 $\mathrm{kg}^{-1}$ ) - and those related to fertilization, irrigation, weed management and roguing. Accounting the problems generated by seminiferous propagation, such as gene segregation and the absence of a practical and costeffective method for early sexual determination, it is necessary to search for alternatives for the large-scale production of C. papaya hermaphrodite plants (Senthilkumar et al. 2014).

Biotechnological techniques have been investigated and used as alternatives to seed propagation. In that respect somatic embryogenesis (SE) has been induced in many different species; many of them crops of commercial interest (Cardoso et al. 2017, Kumaravel et al. 2017, Márquez-López et al. 2018), including papaya (Estrella-Maldonado et al. 2017, Cipriano et al. 2018). The SE relies on the exploitation of totipotency of somatic cell to be reprogrammed into embryonic pathways, leading to bipolar structures and sharing the verys same developmental stages of the zygotic embryogenesis (Oliveira et al. 2017, Yumbla-Orbes et al. 2017). And ultimately, the great potential of scaling-up the processes if coupled with liquid-based culture systems on bioreactors (Posada-Pérez et al. 2017).

Among the several factors influencing somatic embryogenesis, genotype choice is the most remarkable, since there are different embryogenic potentials for the same species. In addition to the genotype, each in vitro culture stage is precisely regulated by many factors, including the level of sucrose in the medium, the type and concentration of growth regulators, photoperiod, gelling agents, exposure time and induction and maturation media (Elmeer 2013).

Manydifficulties areinherenttothedevelopment of a protocol for somatic embryogenesis, for instance, the lack of synchronization in the maturation process, appearance of anomalies, production cost, among others, making it necessary to analyze potential embryogenic responses in vitro for each genotype. Therefore, considering the economic relevance of the UENF/Caliman 01 hybrid, the present work aimed to evaluate adult hermaphrodite tissue somatic embryogenesis controlled by different hormonal and osmotic inducing agents. 


\section{MATERIALS AND METHODS}

The study was carried out at the Laboratory of Plant Tissue Culture, at the North University Center of Espírito Santo, Federal University of Espírito Santo, located in the municipality of São MateusES and at the Laboratory of Tissue Culture II, at the Institute of Biotechnology Applied to Agriculture, Department of Plant Biology, Federal University of Viçosa, in Viçosa-MG.

\section{PLANT MATERIAL}

Five-month-old mother plants of the hybrid Carica papaya L. UENF/Caliman 01, F1 generation, were submitted to sexing, maintaining only the hermaphrodites that had apices pruned (breaking of the apical dominance). After six months, $0.5 \mathrm{~cm}$ apical segments from lateral shoots were used as explants.

\section{IN VITRO ESTABLISHMENT AND MULTIPLICATION}

Apical segments of lateral shoots were individually cultured in test tubes containing $15 \mathrm{~mL}$ of fullstrength MS medium (Murashige and Skoog 1962), with salts, vitamins, myo-inositol $\left(100 \mathrm{mg} \mathrm{L}^{-1}\right)$, sucrose $\left(30 \mathrm{~g} \mathrm{~L}^{-1}\right)$, agar $\left(6.5 \mathrm{~g} \mathrm{~L}^{-1}\right.$, Merck $\left.^{\circledR}\right), 25 \mu \mathrm{M}$ kinetin (6-furfurylaminopurine) and $0.5 \mu \mathrm{M}$ NAA ( $\alpha$-naphthalene acetic acid) (Schmildt et al. 2007). The test tubes with the explants were kept in a growth room, temperature of $27 \pm 2{ }^{\circ} \mathrm{C}$ and 16-hour photoperiod, under a $90 \mu \mathrm{mol} \mathrm{m} \mathrm{m}^{-2} \mathrm{~s}^{-1}$ photosynthetic photon flux obtained with blue/red (3/2) LED lamps (LabPAR: LL-HR/DB-01, Lablumens ${ }^{\circledR}$ ), during a period of 30 days.

Responsive explants were recultured in flasks containing $30 \mathrm{~mL}$ of multiplication medium: MS supplemented with $0.5 \mu \mathrm{M}$ NAA, $2 \mu \mathrm{M}$ BA (6-benzyladenine) and $90 \mu \mathrm{M}$ adenine sulfate; and kept in the growth room for 30 days and subcultured twice, at 30-day intervals. In the preparation of the culture media, the $\mathrm{pH}$ was adjusted to 5.7 before the addition of agar and subsequently autoclaved at $121^{\circ} \mathrm{C}$ and $1.5 \mathrm{~atm}$ for 20 minutes.

\section{INDUCTION OF SOMATIC EMBRYOGENESIS}

For the induction of somatic embryogenesis, under aseptic conditions in a laminar flow chamber, leaf disks (five $\mathrm{mm}$ in diameter) were extracted from in vitro axenic shoots of UENF/Caliman 01 hybrid, and subsequently cultured in $90 \times 15 \mathrm{~mm}$ polystyrene Petri dishes $\left(\mathrm{Kasvi}^{\circledR}\right)$ containing $40 \mathrm{~mL}$ of induction medium (IM) per plate. The IM consisted of fullstrength MS medium with salts, myo-inositol (100 $\left.\mathrm{mg} \mathrm{L}^{-1}\right)$, sucrose $\left(30 \mathrm{~g} \mathrm{~L}^{-1}\right)$, agar $\left(6.5 \mathrm{~g} \mathrm{~L}^{-1}\right.$, Merck $\left.{ }^{\circledR}\right)$, 2,4-D (2,4-dichlorophenoxyacetic acid) $(6,9,12$, 15 , and $18 \mu \mathrm{M}$ ) or 4-CPA (4-chlorophenoxyacetic acid) $(19,22,25,28$, and $31 \mu \mathrm{M})$.

Five Petri dishes were used per treatment, containing five explants on each plate. The explants were incubated in the dark at $27 \pm 2{ }^{\circ} \mathrm{C}$ for 90 days. After this period, the percentage of calogenesis (\%); formation of embryogenic callus (\%) and absolute frequency of somatic embryos (SE callus ${ }^{-1}$ ) were analyzed.

\section{MATURATION OF SOMATIC EMBRYOS}

The embryogenic calli were transferred to the following maturation media (MM): MS medium without growth regulators; MS medium + activated charcoal (AC, $15 \mathrm{~g} \mathrm{~L}^{-1}$ ); MS medium + abscisic acid (ABA, $0.5 \mu \mathrm{M})$; MS medium + ABA $(0.5$ $\mu \mathrm{M})+\mathrm{AC}\left(15 \mathrm{~g} \mathrm{~L}^{-1}\right) ; \mathrm{MS}+\mathrm{ABA}(0.5 \mu \mathrm{M})+$ polyethylene glycol (PEG, $60 \mathrm{~g} \mathrm{~L}^{-1}$ ). The cultures were maintained in a growth room with 16-hour photoperiod, temperature at $27 \pm 2{ }^{\circ} \mathrm{C}$ and a 90 $\mu \mathrm{mol} \mathrm{m} \mathrm{m}^{-2} \mathrm{~s}^{-1}$ photosynthetic photon flux obtained with blue/red LED lamps, during a period of 30 days. The following were analyzed: absolute frequency of SE callus ${ }^{-1}$ (120 days in MM) and number of SE throughout the various development stages (globular, heart, torpedo and cotyledonary).

\section{GERMINATION OF SOMATIC EMBRYOS}

Normal cotyledonary somatic embryos were selected in the most efficient maturation medium 
$\left(\mathrm{MS}+\mathrm{ABA}(0.5 \mu \mathrm{M})+\mathrm{AC}\left(15 \mathrm{~g} \mathrm{~L}^{-1}\right)\right)$ and transferred to germination media (GM): MS media supplemented with different concentrations of $\mathrm{GA}_{3}$ (gibberellic acid) $(0.0,1.44,2.88$, and $4.32 \mu \mathrm{M})$. Plates were maintained in the growth room until rooting of the embryos. The percentage of embryo germination, indicated by primary root protrusion, and percentage of normal plantlets were analyzed.

\section{STATISTICAL ANALYSIS}

In the embryogenic induction experiment, treatments were set in a completely randomized design (CRD), with five replicates and five explants per replicate. The maturation experiment was carried out in a completely randomized design with five treatments and five replicates, containing five explants per replicate. The germination experiment was performed in a completely randomized design with four $\mathrm{GA}_{3}$ concentrations and five replicates, containing five explants per replicate.

Data on the induction of somatic embryogenesis and embryo maturation were submitted to analysis of variance and the means were compared by the Scott-Knott (1974) cluster test at a 5\% significance level, using the Genes software (Cruz 2016). Exceptionally, descriptive statistics of the data were performed for the germination experiment.

\section{RESULTS}

\section{INDUCTION OF SOMATIC EMBRYOGENESIS}

Apices from lateral shoots (Figure 1a) were developed in vitro through the organogenic process in multi-stem shoots, with expanded leaves (Figure 1a-c). Somatic embryogenesis (SE) was initiated from axenic leaf disks of in vitro shoots (Figure 1c) and indirectly via a callus phase (Figure 1d) at different concentrations of 2,4-D and 4-CPA.

Calogenesis responses from leaf explants were more efficient induced at $15(88 \%)$ and $18 \mu \mathrm{M}$ $(100 \%) 2,4-D$, whereas in all 4-CPA concentrations, no significant differences were verified, with means ranging from 84 to $100 \%$ (Table I). However, 4-CPA induced the highest percentages of embryogenic calli, at the concentrations of 25 (96\%), 28, and 31 $\mu \mathrm{M}(94 \%)$, with no statistical differences among them (Table I). The highest frequency of SE callus ${ }^{-1}$ (17.2) was obtained with $25 \mu \mathrm{M}$ 4-CPA (Table I).

\section{MATURATION OF SOMATIC EMBRYOS}

The maturation medium (MM) supplemented with $\mathrm{ABA}$ or $\mathrm{ABA}+\mathrm{PEG}$ induced a low frequency of SEcallus $^{-1}$ (9.6 and 6.6, respectively) (Table II), even in embryos obtained from the 4-CPA treatment. However, in the presence of ABA $(0.5 \mu \mathrm{M})+\mathrm{AC}$ $\left(15 \mathrm{~g} \mathrm{~L}^{-1}\right)$, after 120 days, a higher frequency of SE-callus $^{-1}$ (36.6) was observed, with an increase of $73.77 \%$ in the SE frequency response, when compared to the absence of AC in the MM (Table II; Figure 1k, 1).

Embryogenic calli of the hybrid papaya UENF/ Caliman 01 from 4-CPA induction and cultured in $\mathrm{MM}\left(\mathrm{ABA}(0.5 \mu \mathrm{M})+\mathrm{AC}\left(15 \mathrm{~g} \mathrm{~L}^{-1}\right)\right)$ showed enhanced embryo development in all stages, in addition to larger numbers of somatic embryos per callus (Table II, Figure 1 k, 1), reaching the highest average of cotyledonary embryos (7.6), when compared to the medium supplemented with only AC (15 $\left.\mathrm{g} \mathrm{L}^{-1}\right)$ (4.8) (Table II).

\section{GERMINATION OF COTILEDONARY EMBRYOS}

In the embryo germination phase, the absence of growth regulator did not promote germination. In the presence of $\mathrm{GA}_{3}$, it was observed a $20 \%$ germination of somatic embryos at $1.44 \mu \mathrm{M}$ and $40 \%$ at $2.88 \mu \mathrm{M}$, after 30 days, and conversions of $25 \%$ and $66 \%$ into plantlets, respectively (Table III).

\section{DISCUSSION}

\section{INDUCTION OF SOMATIC EMBRYOGENESIS}

Auxins are important in the process of embryogenic induction, since they regulate the cell cycle and promote cell differentiation (Rocha et al. 2012). In the present study, 2,4-D presented a negative effect, promoting low responsiviness in calli (Figure 1g; Table I). Also, abnormal embryos were observed 


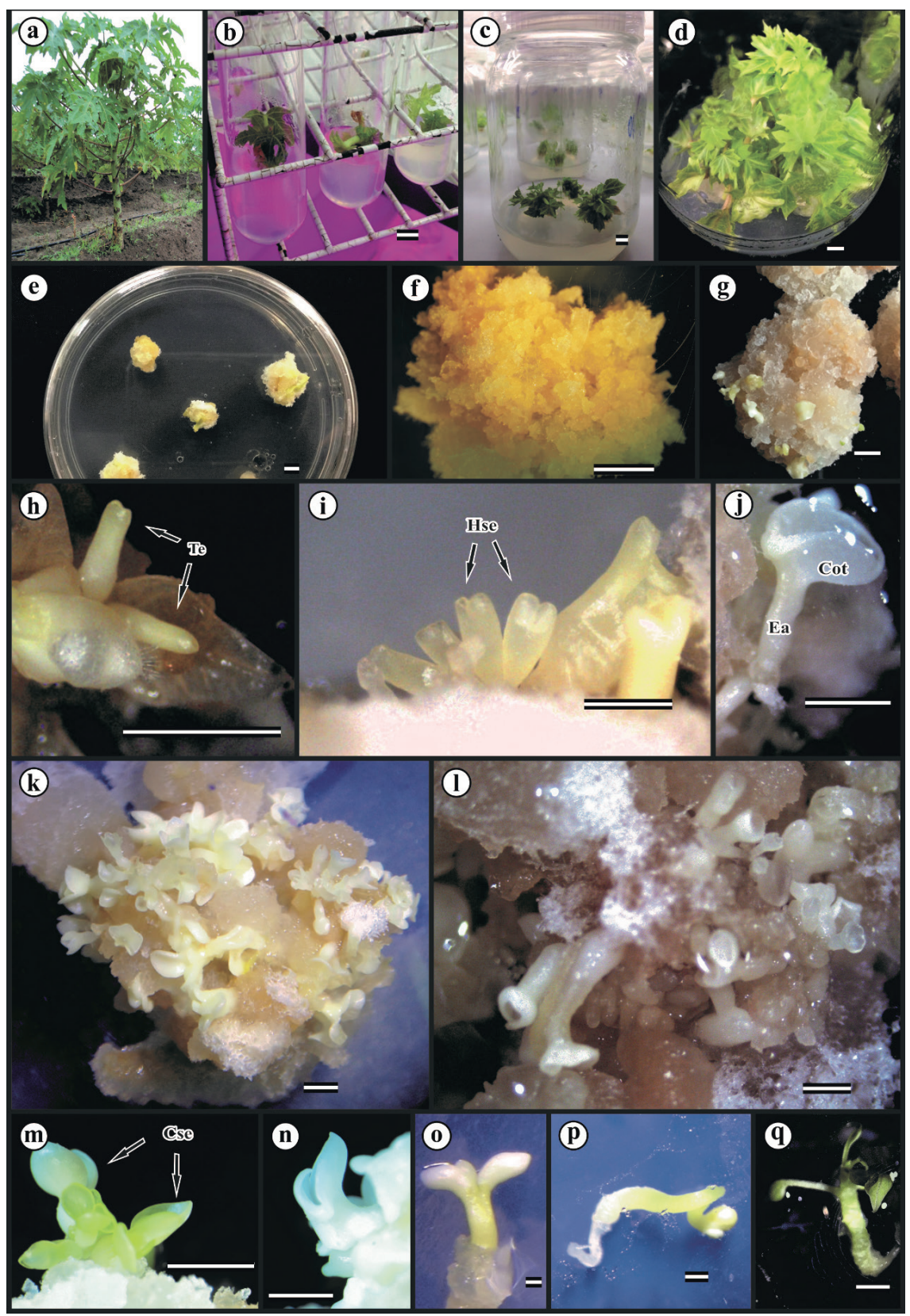

Figure 1 - Somatic embryogenesis from axenic leaf explants of in vitro shoots of the hybrid hermaphrodite papaya UENF/Caliman 01. (a) Six-month-old mother plant. (b) Apical segments of lateral shoots. (c and d) In vitro established shoots. (e) Calli formed in induction medium (40 days). (f) Growth of friable callus. (g) Embryogenic callus induced with 2,4-D in maturation medium (MM) consisting of ABA $(0.5 \mu \mathrm{M})+\mathrm{AC}\left(15 \mathrm{~g} \mathrm{~L}^{-1}\right)$. (h) Somatic embryos in torpedo stage. (i) Somatic embryos at different development stages. (j) Normal cotyledonary embryo. (k) Embryogenic callus induced with 4-CPA in $\mathrm{MM}$ consisting of ABA $(0.5 \mu \mathrm{M})+\mathrm{AC}\left(15 \mathrm{~g} \mathrm{~L}^{-1}\right)$. (l) Somatic embryos in MM. (m) Normal somatic embryo with developed cotyledonary leaves. (n and o) Morphologically normal cotyledonary embryos. (p) Germinated abnormal embryo - monocotyledons. (q) Conversion of cotyledonary embryo into plantlet. Abbreviations: cot. cotyledons; ea. embryonic axis; Cse. Cotyledonary-shape somatic embryo; Hse. Heart-shaped somatic embryo; Tse. Torpedo-shape somatic embryo. Bar $=10 \mathrm{~mm}$ (a, b, c and d) and $1.0 \mathrm{~mm}$ (e-o). 
TABLE I

In vitro morphogenic responses of leaf disks from axenic shoots of the hybrid hermaphrodite papaya UENF/Caliman 01, after 90 days of culture in induction medium supplemented with 2,4-D or 4-CPA.

\begin{tabular}{|c|c|c|c|c|}
\hline \multirow[b]{2}{*}{ Auxin } & \multirow[b]{2}{*}{$\begin{array}{c}\text { Concentration } \\
(\mu \mathrm{M})\end{array}$} & \multicolumn{3}{|c|}{ Characteristics analyzed } \\
\hline & & $\begin{array}{c}\text { Calogenesis } \\
(\%)\end{array}$ & $\begin{array}{c}\text { Embryogenic calluses } \\
(\%)\end{array}$ & $\begin{array}{l}\text { Absolute frequency of } \\
\text { SE } \text { callus }^{-1}\end{array}$ \\
\hline \multirow{5}{*}{$2,4-\mathrm{D}$} & 6 & $36 b^{(1)}$ & $4 \mathrm{c}$ & $1.0 \mathrm{~d}$ \\
\hline & 9 & $44 \mathrm{~b}$ & $8 \mathrm{c}$ & $2.0 \mathrm{~d}$ \\
\hline & 12 & $56 \mathrm{~b}$ & $16 \mathrm{c}$ & $1.6 \mathrm{~d}$ \\
\hline & 15 & $88 \mathrm{a}$ & $12 \mathrm{c}$ & $2.4 \mathrm{~d}$ \\
\hline & 18 & $100 \mathrm{a}$ & $20 \mathrm{c}$ & $0.6 \mathrm{~d}$ \\
\hline \multirow{5}{*}{ 4-CPA } & 19 & $96 \mathrm{a}$ & $28 \mathrm{~b}$ & $6.4 \mathrm{c}$ \\
\hline & 22 & $84 \mathrm{a}$ & $56 \mathrm{~b}$ & $10.6 \mathrm{~b}$ \\
\hline & 25 & $100 \mathrm{a}$ & $96 \mathrm{a}$ & $17.2 \mathrm{a}$ \\
\hline & 28 & $96 \mathrm{a}$ & $84 \mathrm{a}$ & $10.0 \mathrm{~b}$ \\
\hline & 31 & $100 \mathrm{a}$ & $84 \mathrm{a}$ & $6.2 \mathrm{c}$ \\
\hline
\end{tabular}

${ }^{(1)}$ Means followed by the same letters do not differ statistically, at $\mathrm{p} \leq 0.05$, by the Scott-Knott mean clustering test. 2,4-D. 2,4-dichlorophenoxyacetic acid; 4-CPA. 4-chlorophenoxyacetic acid; SE. somatic embryo; MS. Murashige and Skoog.

TABLE II

Average absolute frequency SE callus ${ }^{-1}$ and number of somatic embryos at different development stages of the hybrid hermaphrodite papaya UENF/Caliman 01 obtained from leaf explants of in vitro axenic shoots induced with 2,4-D and 4-CPA, after 120 days of culture.

\begin{tabular}{|c|c|c|c|c|c|c|}
\hline \multirow[b]{2}{*}{$\begin{array}{c}\text { Auxinic } \\
\text { induction SE }\end{array}$} & \multirow[b]{2}{*}{$\begin{array}{l}\text { Maturation medium } \\
\text { (MM) }\end{array}$} & \multirow[b]{2}{*}{$\begin{array}{l}\text { Absolute } \\
\text { frequency } \\
\text { SE callus }{ }^{-1}\end{array}$} & \multicolumn{4}{|c|}{ Number SE at different stages } \\
\hline & & & Gse & Hse & Tse & Cse \\
\hline \multirow{5}{*}{$2,4-\mathrm{D}$} & MS without growth regulator & $4.0 \mathrm{e}^{(1)}$ & $0.2 \mathrm{~d}$ & $0.0 \mathrm{~d}$ & $0.2 \mathrm{~d}$ & $0.0 \mathrm{~d}$ \\
\hline & $\mathrm{MS}+\mathrm{ABA}(0.5 \mu \mathrm{M})$ & $2.0 \mathrm{e}$ & $1.2 \mathrm{~d}$ & $0.0 \mathrm{~d}$ & $0.4 \mathrm{~d}$ & $0.0 \mathrm{~d}$ \\
\hline & $\mathrm{MS}+\mathrm{AC}\left(15 \mathrm{~g} \mathrm{~L}^{-1}\right)$ & $1.6 \mathrm{e}$ & $0.8 \mathrm{~d}$ & $0.0 \mathrm{~d}$ & $1.2 \mathrm{~d}$ & $0.0 \mathrm{~d}$ \\
\hline & $\mathrm{MS}+\mathrm{ABA}(0.5 \mu \mathrm{M})+\mathrm{AC}\left(15 \mathrm{~g} \mathrm{~L}^{-1}\right)$ & $2.4 \mathrm{e}$ & $0.6 \mathrm{~d}$ & $0.6 \mathrm{~d}$ & $1.2 \mathrm{~d}$ & $0.0 \mathrm{~d}$ \\
\hline & $\mathrm{MS}+\mathrm{ABA}(0.5 \mu \mathrm{M})+\mathrm{PEG}\left(60 \mathrm{~g} \mathrm{~L}^{-1}\right)$ & $6.0 \mathrm{e}$ & $0.0 \mathrm{~d}$ & $0.0 \mathrm{~d}$ & $0.6 \mathrm{~d}$ & $0.0 \mathrm{~d}$ \\
\hline \multirow{5}{*}{ 4-CPA } & MS without growth regulator & $9.4 \mathrm{c}$ & $1.6 \mathrm{~d}$ & $2.6 \mathrm{c}$ & $4.0 \mathrm{c}$ & $1.4 \mathrm{c}$ \\
\hline & $\mathrm{MS}+\mathrm{ABA}(0.5 \mu \mathrm{M})$ & $21.4 \mathrm{~b}$ & $2.8 \mathrm{c}$ & $0.8 \mathrm{~d}$ & $4.2 \mathrm{c}$ & $1.6 \mathrm{c}$ \\
\hline & $\mathrm{MS}+\mathrm{AC}\left(15 \mathrm{~g} \mathrm{~L}^{-1}\right)$ & $9.6 \mathrm{c}$ & $5.0 \mathrm{~b}$ & $5.0 \mathrm{~b}$ & $6.6 \mathrm{~b}$ & $4.8 \mathrm{~b}$ \\
\hline & $\mathrm{MS}+\mathrm{ABA}(0.5 \mu \mathrm{M})+\mathrm{AC}\left(15 \mathrm{~g} \mathrm{~L}^{-1}\right)$ & $36.6 \mathrm{a}$ & $10.4 \mathrm{a}$ & $8.6 \mathrm{a}$ & $10.0 \mathrm{a}$ & $7.6 \mathrm{a}$ \\
\hline & $\mathrm{MS}+\mathrm{ABA}(0.5 \mu \mathrm{M})+\mathrm{PEG}\left(60 \mathrm{~g} \mathrm{~L}^{-1}\right)$ & $6.6 \mathrm{~d}$ & $2.6 \mathrm{c}$ & $0.6 \mathrm{~d}$ & $2.2 \mathrm{~d}$ & $1.2 \mathrm{c}$ \\
\hline
\end{tabular}

${ }^{(1)}$ Means followed by the same letters do not differ statistically, at $\mathrm{p} \leq 0.05$, by the Scott-Knott mean clustering test. 2,4-D. 2,4-dichlorophenoxyacetic acid; 4-CPA. 4-chlorophenoxyacetic acid; ABA. abscisic acid; AC. activated charcoal; Cse. Cotyledonary-shaped somatic embryo; Gse. Globular-shaped somatic embryo; Hse. Heart-shaped somatic embryo; MS. Murashige and Skoog; PEG. polyethylene glycol; SE: somatic embryo; Tse. Torpedo-shape somatic embryo.

when analyzing embryogenic induction in different concentrations of 2,4-D and 4-CPA(Figure 1). On the other hand, 4-CPA had a positive effect, especially at the concentration of $25 \mu \mathrm{M}$ (Figure 1k; Table I).
The induction of zygotic embryos in Jarilla heterophylla (Caricaceae) with 2,4-D (18.09 $\mu \mathrm{M})$ promoted a negative effect on callus production, similar to the control $(0 \mu \mathrm{M})$, and a large number 
TABLE III

Percentage of germination and plantlet conversion from cotyledonary somatic embryos of the hybrid hermaphrodite papaya (UENF/Caliman 01), obtained from MM (MS + ABA $(0.5 \mu \mathrm{M})+\mathrm{AC}\left(15 \mathrm{~g} \mathrm{~L}^{-1}\right)$, in germination medium (GM) with different concentrations of $\mathrm{GA}_{3}$.

\begin{tabular}{cccc}
\hline GM & $\begin{array}{c}\text { SE germinated } \\
(\mathbf{\%})\end{array}$ & $\begin{array}{c}\text { SE not germinated } \\
(\%)\end{array}$ & $\begin{array}{c}\text { Plantlets } \\
(\%)\end{array}$ \\
\hline MS without growth regulator & 0 & 100 & 0 \\
MS $+\mathrm{GA}_{3}(1.44 \mu \mathrm{M})$ & 20 & 80 & 25 \\
$\mathrm{MS}+\mathrm{GA}_{3}(2.88 \mu \mathrm{M})$ & 40 & 60 & 66 \\
$\mathrm{MS}+\mathrm{GA}_{3}(4.32 \mu \mathrm{M})$ & 0 & 100 & 0 \\
\hline
\end{tabular}

ABA. abscisic acid; AC. activated charcoal; SE. Somatic embryos. GA . gibberellic acid; MM. maturation medium; MS. Murashige and Skoog.

of embryos with multiple cotyledons was observed, suggesting that this auxin is probably unfit for this species under the conditions studied (Nuño-Ayala et al. 2012). However, if provided in pulses for certain periods, this phytohormone can promote cell polarity and normal embryo development (Moon et al. 2015).

The addition of auxins to the culture medium may increase the totipotency of cells with the ability to proliferate somatic embryos (Garcia et al. 2011). According to Guerra et al. (1999), both genotype of the explant donor mother plant and the auxin type play essential roles in the embryogenic competence. In the medium supplemented with 2,4-D, immature zygotic embryos of $C$. papaya L. were sufficient to produce highly embryogenic callus (Clarindo et al. 2008, Abreu et al. 2014).

Reports on the use of 4-CPA in somatic embryogenesis in papaya are still scarce. Nonetheless, Cipriano etal.(2018) have successfully reported the induction of cotyledonary leaves in papaya cv. Golden THB. According to these authors, auxins may trigger different induction responses in tissues of the same genotype, even among auxins with very subtle differences (presence of a chlorine atom in the carbon in position 2 of the 2,4-D phenol ring). In addition, cell response to the inducer is related to the number of receptors present on the cell surface, and may vary according to the type of tissue induced (Loschiavo et al. 1991).
The results obtained in the present work are in agreement with those reported by Cipriano et al. (2018), allowing to infer that papaya cv. Golden THB shows greater sensitivity and responsiveness to 4-CPA, as compared to 2,4-D.

By testing different auxins on embryogenic responsesinimmaturewheatembryos, theapplication of 2,4,5-T (2,4,5-trichlorophenoxyacetic acid) led to the formation of visible sites of embryogenic calli with several embryos, a pattern similar to that found for the 4-CPA induction (Miroshnichenko et al. 2013). According to the authors, although the use of 4-CPA generated a lower number of embryos, it promoted a more rapid development. The use of 2,4-D stimulated the formation of denser and more compact embryogenic calli, and the embryos developed in a more synchronized pattern, when compared to the other auxins.

The induction of cotyledonary leaves of papaya cv. Golden THB with 2,4-D presented low efficiency, unlike 4-CPA $(25 \mu \mathrm{M})$, which provided high percentages of embryogenic calli $(91.67 \%)$ and average number of embryos (65.75) (Cipriano et al. 2018). However, using 2,4-D (9.04 or 45.24 $\mu \mathrm{M})$, Almeida et al. (2001) observed $41.7 \%$ of embryogenic calli in the hybrid Tainung 01. Sun et al. (2011), from immature seeds of papaya cv. Sunrise, obtained $68.7 \%$ callus frequency in MS medium containing $2.4-\mathrm{D}(6.0 \mu \mathrm{M})$, NAA $(2.5 \mu \mathrm{M})$ and kinetin [6-furfurylamino purine] $(4.0 \mu \mathrm{M})$. 
Somatic embryogenesis from zygotic embryos of papaya cv. Co7, with 2,4-D $(9.05 \mu \mathrm{M})$, resulted in a high percentage $(87 \%)$ of calli, $75.12 \%$ of which were embryogenic (Anandan et al. 2012). However, the authors observed a decrease in calogenesis when the 2,4-D concentration was increased from 18.09 to $72.36 \mu \mathrm{M}(47.4 \%)$. Koehler et al. (2013) verified a high correlation between the low concentration of 2,4-D $(9.05 \mu \mathrm{M})$ and the high frequency of friable embryogenic calli (74\%) from leaf explants of Carica papaya L., after 30 days of culture.

In the induction of Jarilla heterophylla zygotic embryos, the presence of adenine sulphate in the previous medium had inhibitory effects on callus generation from initial explants, resulting in 14 somatic embryos, whereas in the absence of this cytokinin, 74 somatic embryos were obtained (Nuño-Ayala et al. 2012). Similar effects may have been induced in the present work. The transfer of shoots induced in adenine sulphate medium (Figure 1c) to the growth regulatorfree medium and their maintenance for a certain period of time for lessening endogenous levels of this cytokinin may have contributed for the low frequency of somatic embryos of the hybrid hermaphrodite papaya UENF/Caliman 01, induced in a 2,4-D-supplemented medium.

Cells may become competent for somatic embryogenesis provided that the interaction among endogenous and exogenous factors, such as the concentration and type of growth regulator, are balanced, triggering a series of molecular events that may affect gene expression and determine the differentiation into somatic embryos (Nolan et al. 2014). It is known that in plants, auxin is distributed directly from cell to cell through the polar auxin transport (PAT) driven by auxin influx (AUX1/LAXs) and efflux (PINs) proteins. In Arabidopsis thaliana, PAT plays an important role in the formation of stem and root apical meristems during somatic embryogenesis (SE). In this regard, Estrella-Maldonado et al. (2017) found in papaya that auxin influx transport (AIT) genes $\left(C p L A X_{1}\right.$, ${ }_{3}$ ) are apparently more related to the development of somatic embryos in the torpedo and cotyledonary stages. In contrast, auxin efflux transduction (AET) genes $\left(C P P I N_{1}, 3,4\right)$ appear to be related to the development of SEs at different stages (from globular to cotyledonary). Furthermore, when the mature somatic embryo is converted into plantlet, the expression of the transporter genes $C p A U X_{1}$, $C p L A X_{1}, C p L A X_{2}, C p L A X_{3}, C p P I N_{1}, C p P I N_{3}$ and $\mathrm{CpPIN}_{4}$ become higher.

\section{MATURATION OF SOMATIC EMBRYOS}

Maturation is an important phase in somatic embryogenesis, and the addition of maturation promoters, such as polyethylene glycol (PEG), abscisic acid (ABA) and activated charcoal (AC) is crucial for the conversion of embryos into their respective stages of development (CalicDragosavac et al. 2010).

In the present work, the highest frequency of SE callus ${ }^{-1}$ was obtained in $\mathrm{ABA}(0.5 \mu \mathrm{M})+\mathrm{AC}(15$ $\mathrm{g} \mathrm{L}^{-1}$ ) maturation medium (Table II). Considering AC supplementation, its effect is associated with the adsorption of toxic substances, such as phenolic compounds, among other metabolites, which are responsible for the inhibition of morphogenesis, a process that results from cell division and differentiation (Fridborg et al. 1978, Martínez et al. 2015). According to Cipriano et al. (2018), embryogenic calli of papaya cv. Golden THB in medium supplemented with $\mathrm{ABA}(0.5 \mu \mathrm{M})+$ $\mathrm{AC}\left(15 \mathrm{~g} \mathrm{~L}^{-1}\right)$ showed a higher frequency of SE callus $^{-1}$ and inhibition of early germination. This is associated with the fact that ABA aids in the formation and maturation of a large number of high-quality somatic embryos capable of developing into plantlets (Guerra et al. 1999). However, in the absence of ABA, the maturation phase results in poorly developed, often abnormal, somatic embryos presenting low capacity for 
germination and plantlet growth (Cipriano et al. 2018). ABA accumulates in the higher plants as a result of water stress (Pacheco et al. 2011) and is involved in various physiological functions, such as stomatal movement (Lim et al. 2015) and dormancy (Kermode 2005).

In papaya, transcription factors (TFs) related to the WRKY gene are involved in the response to water stress and are controlled by a family of proteins that increase TF807.3, TF43.76, TF5.242 and TF21,156 by 14.1, 19.2, 13.2, and 13.1 fold, respectively (Pan and Jiang 2015). In Solanum chacoense Bitt., the ScWRKY1 protein is expressed at almost undetectable levels during seed development, low levels in stems, roots and petals, high levels in leaves, and is strongly expressed transiently in fertilized egg cells bearing embryos at the final torpedo stage, indicating a specific role during embryogenesis (Lagacé and Matton 2004). In Gossypium raimondii and Gossypium hirsutum under abiotic stress (water and flooding), GhWRKY expression was very high during fiber development, foliar senescence, anthers and tissues (roots, stems, leaves and embryos), which implies that $W R K Y$ genes have a role in stress response (Dou et al. 2014). The expression pattern observed for ScWRKY1 in Solanum chacoense embryos at the torpedo stage suggests that transcription factors of the family may be WRKY, involved in crucial events during embryogenesis and seed development into seedlings (Lagacé and Matton 2004).

Krassimira and Alexandrova (2002) found out that $D G E 1$ and $D G E 2$ genes transcripts, containing a WRKY domain, related to somatic embryogenesis in Arabidopsis thaliana with possible regulatory nuclear functions. Pan and Jiang (2015) suggest that the high homology of WRKY in papaya may be related to similar functions of homologous genes in other species.

In the conifer Picea abies L. Karst., the combination of ABA and AC was beneficial, increasing the yield of cotyledonary somatic embryos, the number of genotypes forming cotyledonary embryos, and reducing the cost of embryo production. These embryos presented increased size, had larger apical regions, became more similar to zygotic embryos in shape, and showed higher percentage of epicotyl development during germination (Pullman et al. 2005).

The maturation medium supplemented with ABA $(0.5 \mu \mathrm{M})+\mathrm{AC}\left(15 \mathrm{~g} \mathrm{~L}^{-1}\right)$ from calli induced with $25 \mu \mathrm{M}$ 4-CPA produced the highest number of embryos at all maturation stages (Table II). Anandan et al. (2012), using liquid medium supplemented with ABA (39.7 $\mu \mathrm{M})$, obtained superior yield of embryos in the cotyledonary stage, while in the absence or lower concentrations of ABA, this yield was lower and with a high frequency of abnormal embryos.

Crocus explants (Crocus oliveri ssp.) exhibited higher proliferation and development of embryos in the cotyledonary phase in MM supplemented with IAA $(11.4 \mu \mathrm{M})+$ thidiazuron - TDZ $(9.08 \mu \mathrm{M})+$ ABA (378.3 $\mu \mathrm{M})$ (Verma et al. 2016). Similarly, Ju et al. (2014) observed that the addition of AC $(0.5 \%)$ in the $\mathrm{MM}$ increased the maturation percentage $(87.52 \%)$ in Cucumis anguria L., in relation to the absence of AC (35.51\%). According to Martínez et al. (2015), the supplementation of the basal MS medium with AC $(0.4 \%)$, sucrose $(3 \%)$ and silver thiosulfate $(20 \mu \mathrm{M})$ was the most adequate for the production of cotyledonary embryos and subsequent germination (88.9\%) in Quercus rubra.

The maturation medium with PEG 6000 (60 $\mathrm{g} \mathrm{L}^{-1}$ ) caused reduction in the development of somatic embryos at all stages (Table II). In mango, Pliego-Alfaro et al. (1996) observed that the further development from SE at the cotyledonary stage was significantly inhibited by ABA and mannitol treatments. Osmotic agents, such as high molecular weight PEG, reduce the water potential of the culture medium and caused a substantial water stress in cells. 
The maturation of immature zygotic embryos of the hybrid papaya UENF/Caliman 01 in medium with PEG $3350\left(60 \mathrm{~g} \mathrm{~L}^{-1}\right)$ resulted in higher maturation responses $(83.3 \%$ ) (Heringer et al. 2013). Vale et al. (2014), adding PEG (6\%) to the maturation medium, obtained 40 cotyledonary somatic embryos per callus in the hybrid UENF/ Caliman 01, in which the proteins in the range of 34-87 KDa were more abundant, suggesting that these proteins can be fundamental in the maturation process, acting as biochemical markers. Chagas et al. (2018) found that the increase in PEG 6000 concentrations reduced the normality of somatic embryos of papaya cv. Golden THB by approximately $54 \%$ to the maximum concentration tested $\left(70 \mathrm{~g} \mathrm{~L}^{-1}\right)$, when compared to its absence.

The formation of morphological abnormalities in somatic embryos was observed in all media investigated in the present study, such as monocotyledons (Figure 1p), multi-cotyledons and fused cotyledons (images not shown). Variations like these were also observed in the development of somatic embryos of papaya cv. Golden (Anandan et al. 2012), cv. Golden THB (Cipriano et al. 2018) and cv. Golden as well as the F2 generation of the hybrid UENF/Caliman 01 (Vale et al. 2014). This is due in part to the stress caused by the culture of these embryos in sealed flasks, aggravating the lack of aeration, accumulation of ethylene and drought of the culture medium.

\section{GERMINATION OF COTILEDONARY EMBRYOS}

No somatic embryos were able to germinate in the medium without growth regulator, but in the presence of $\mathrm{GA}_{3}$, there was low germination at the concentrations studied. The low efficiency of $\mathrm{GA}_{3}$ is probably associated with the accumulation of growth regulators, such as ABA in papaya tissues in the maturation phase, which induces the production of LEA (Late Embryogenesis Abundant) proteins, conferring tolerance to embryo desiccation, and occasionally establishing physiological dormancy. The genes codifying these proteins are expressed in late stages of embryogenesis; however, the production of LEAs can be induced when somatic and zygotic embryos are treated with ABA (IkedaIwai et al. 2002). In Acer platanoides L., the transcription of ABI5 and RGL2 proteins, which is mediated by $\mathrm{ABA}$, probably blocked germination by inhibiting meristem activity and preventing procambial cell differentiation, respectively (Staszak et al. 2017).

In Arabidopsis thaliana, 51 genes encoding LEA proteins were identified and classified into nine distinct groups, in response to ABA signaling and/ or low temperature (Hundertmark and Hincha 2008, Yoshida et al. 2015). Negin and Moshelion (2016) have confirmed, after treatment with ABA, which genes are upregulated, including those encoding LEAs, transcription factors and osmoprotectants. Proteins can be used as markers for somatic embryogenesis; therefore, associating embryonic stages and their changes in protein profiles with embryo development (Campalans et al. 2000).

A series of studies in plants of different species suggest that $\mathrm{GA}_{3}$ stimulates genes that are mainly involved in elongation and cell division (Zimmerman et al. 1993). When studying hormonal transporters in plants, Park et al. (2017) found that multiple members of the NPF family, such as NPF3.1, that import $\mathrm{GA}_{3}$ are dependent on the $\mathrm{pH}$ of the medium. According to Chen et al. (1987), germination is followed by increased regulation of a number of stress response genes and membrane transporter, and greening associated with the over-regulation of several genes encoding the photosynthetic components and chloroplasts. In this sense, Posada-Pérez et al. (2017) verified maximum germination (100\%) of cv. Maradol in culture medium in the temporary immersion system RITA ${ }^{\circledR}$ with combination of $\mathrm{GA}_{3}(2.90 \mu \mathrm{M})$ and $\mathrm{BAP}(0.02 \mu \mathrm{M})$. 
In somatic embryos of papaya, low germination and callus production are observed at the base of the radicle, as reported in the present work (Figure 1o), also hyperhydric plantlets are commonly observed (Ascencio-Cabral et al. 2008). When testing gelling agents on the culture medium, these authors found an alternative to minimize the problems mentioned above, producing plantlets free of anomalies with the use of Bactoagar $^{\circledR}$ (7.5 $\mathrm{g} \mathrm{L}^{-1}$ ) and obtaining $41 \%$ germination, which is superior to that obtained with $\operatorname{Agar}^{\circledR}\left(7.0 \mathrm{~g} \mathrm{~L}^{-1}\right)$ and Fitagel ${ }^{\circledR}\left(3.0 \mathrm{~g} \mathrm{~L}^{-1}\right): 10$ and 23\%, respectively. The results of the present study are in accord with those obtained by Ascencio-Cabral et al. (2008), who observed that the use of agar as a solidifying agent in the MS medium and supplementation with $\mathrm{GA}_{3}$ resulted in low germination and formation of abnormal embryos, despite the absence of embryo hyperhydricity (data not shown).

In many embryogenic systems, SE transfer to growth media free of growth regulators increases the SE development and its conversion to seedlings (Ju et al. 2014). Embryo maturation in agar-solid medium resulted in a high germination rate $(48 \%)$ when compared to maturation in the presence of gellan gum $(30 \%)$, produced by the bacterium Sphingomonas elodea (Márquez-Martín et al. 2009).

Embryos require radicle stimulation to grow and, for this reason there was low efficiency with their maintenance in MS medium with absence and presence of $\mathrm{GA}_{3}$ at the concentrations studied (Table III), suggesting that the explanation may rely on the type and concentrations of the growth regulator tested. Wu et al. (2012) observed in shoots of papaya cv. Meizhonghong highest percentage (90\%) and quality of rooting in MS + IBA (indole3-butyric acid) medium (1.44 and $2.88 \mu \mathrm{M}$ for three and one day, respectively), prior to transfer to medium $3 / 2 \mathrm{MS}+\mathrm{AC}\left(0.5 \mathrm{~g} \mathrm{~L}^{-1}\right)+\operatorname{sucrose}\left(5 \mathrm{~g} \mathrm{~L}^{-1}\right)$, and the exposure of these explants to IBA (4920.3 $\mu \mathrm{M}$ ) for 10 seconds resulted in $84.7 \%$ rooting and with normal roots. Therefore, it is relevant to study the effect of other auxins on embryos of the hybrid hermaphrodite papaya UENF/Caliman 01, such as IBA, in different concentrations, exposure times in solid medium and pulses in liquid medium for a better development of the root system.

\section{CONCLUSIONS}

Embryogenic efficiency of axenic leaf explants from in vitro shoots of the hybrid hermaphrodite papaya UENF/Caliman 01 is higher when using 4-CPA $(25 \mu \mathrm{M})$.

Maturation and conversion of the somatic embryos arehigher using MS medium supplemented with $\mathrm{ABA}(0.5 \mu \mathrm{M})+\mathrm{AC}\left(15 \mathrm{mg} \mathrm{L}^{-1}\right)$.

Germination of cotyledonary somatic embryos presents a higher average with $\mathrm{GA}_{3}(2.88 \mu \mathrm{M})$.

\section{ACKNOWLEDGMENTS}

Dissertation presented by the first author to the Universidade Federal do Espírito Santo as part of the requirements of the Programa de Pós-Graduação em Agricultura Tropical, to obtain the Master's Degree in Tropical Agriculture. The authors are grateful for the Coordenação de Aperfeiçoamento de Pessoal de Nível Superior (CAPES), the Conselho Nacional de Desenvolvimento Científico e Tecnológico $(\mathrm{CNPq})$ and Fundação de Amparo à Pesquisa e Inovação do Espírito Santo (FAPES) to finance this work. The company Caliman Agrícola S/A, on behalf of Geraldo Antônio Ferreguetti, for the removal of explants from parent plants of UENF/Caliman 01.

\section{AUTHOR CONTRIBUTIONS}

DS GOUVEA, K CHAGAS, JLD CIPRIANO, JC LOPES, CP ARAUJO and RS ALEXANDRE wrote the manuscript; ER SCHMILDT, responsible for statistics; WC OTONI, coorientated the work, as one of the greatest experts in this area in Brazil; O SCHMILDT, helped establish the adult material in 
vitro; all authors critically revised the manuscript and approved the final version.

\section{REFERENCES}

ABREU IS, CARVALHO CR AND SOARES FAF. 2015. Early sex discrimination in Carica papaya by nuclei FISH. Euphytica 206: 667-676.

ABREU IS, CARVALHO CR AND CLARINDO WR. 2014. Massal induction of Carica papaya L. 'Golden' somatic embryos and somaclones screening by flow cytometry and cytogenetic analysis. Cytologia 79: 475-484.

ALMEIDA EP, OLIVEIRA RP AND DANTAS JLL. 2001. Indução e desenvolvimento de calos e embriões somáticos em mamoeiro. Sci Agr 58: 51-54.

ANANDAN R, SUDHAKARA D, BALASUBRAMANIAN P AND GUTIÉÝRREZ-MORAB A. 2012. In vitro somatic embryogenesis from suspension cultures of Carica papaya L. Sci Hortic 136: 43-49.

ASCENCIO-CABRAL A, GUTIÉRREZ-PULIDO $\mathrm{H}$, RODRÍGUEZ-GARAY B AND GUTIÉRREZ-MORA A. 2008. Plant regeneration of Carica papaya L. through somatic embryogenesis in response to light quality, gelling agent and phloridzin. Sci Hortic 118: 155-160.

BRAPEX - ASSOCIAÇÃO BRASILEIRA DOS PRODUTORES E EXPORTADORES DE PAPAYA. 2016. Exportação de mamão do ES para os Estados Unidos será facilitada. Disponível em: http://www.brapex.net/2013/ noticia.asp?id=232. Acesso em: 15 fev. 2016.

CALIC-DRAGOSAVAC D, ZDRAVKOVI-KORA S, BOHANEC B, RADOJEVI L, VINTERHALTER B, STEVOVI S, CINGEL A AND SAVI J. 2010. Effect of activated charcoal, abscisic acid and polyethylene glycol on maturation, germination and conversion of Aesculus hippocastanum androgenic embryos. Afr J Biotechnol 9: 3786-3793.

CAMPALANS A, PAGÈS M AND MESSEGUER R. 2000. Protein analysis during almond embryo development. Identification and characterization of a late embryogenesis abundant protein. Plant Physiol Biochem 38: 449-457.

CARDOSO JC, CURTOLO M, LATADO RR AND MARTINELLI AP. 2017. Somatic embryogenesis of a seedless sweet orange (Citrus sinensis (L.) Osbeck). In Vitro Cell Dev-P1 53: 619-623.

CHAGAS K, CIPRIANO JLD, LOPES JC, SCHMILDT ER, OTONI WC AND ALEXANDRE RS. 2018. The effects of an osmoregulator, carbohydrates and polyol on maturation and germination of 'Golden THB' papaya somatic embryos. An Acad Bras Cienc 90: 3433-3447.

CHEN CC, WANG PJ AND MAEDA E. 1987. Somatic embryogenesis and plant regeneration in Carica papaya L. tissue culture derived from root explants. Plant Cell Rep 6: $348-351$.
CIPRIANO JLD, CRUZ ACF, MANCINI KC, SCHMILDT ER, LOPES JC, OTONI WC AND ALEXANDRE RS. 2018. Somatic embryogenesis in Carica papaya as affected by auxins and explants, and morphoanatomicalrelated aspects. An Acad Bras Cienc 40: 385-400.

CLARINDO WR, CARVALHO CR, ARAÚJO FS, ABREU IS AND OTONI WC. 2008. Recovering polyploid papaya in vitro regenerants as screened by flow cytometry. Plant Cell Tiss Org Cult 92: 207-214.

CNABRASIL. 2016. O município de Linhares, no Espírito Santo, é modelo na produção de mamão no País. Disponível em: http://www.cnabrasil.org.br/noticias/o-municipiode-linhares-no-espirito-santo-e-modelo-na-producao-demamao-no-pais. Acesso em: 11 fev. 2017.

COSTA AFS, DANTAS JLL, PEREIRA MG, CATTANEO LF, COSTA NA AND MOREIRA SO. 2013. Botânica, melhoramento e variedades. Informe Agropecuário: Cultivo do mamoeiro 34: 14-24.

CRUZ CD. 2016. Genes Software - extended and integrated with the R, Matlab and Selegen. Acta Sci-Agro 38: 547552.

DOU L, ZHANG X, PANG C, SONG M, WEI H, SHULI F AND YU S. 2014. Genome-wide analysis of the WRKY gene family in cotton. Mol Genet Genomics 6: 1103-1121.

ELMEER KES. 2013. Factors regulating somatic embryogenesis in plants. In: Aslam J, Srivastava PS and Sharma MP (Eds), Somatic embryogenesis and gene expression. New Delhi: Narosa Publishing House, 56-81.

ESTRELLA-MALDONADO H, POSADA-PÉREZ L, TALAVERA MC, BARREDO PF, GÓMEZ-KOSKY R AND SANTAMARIA JM. 2017. The expression of CpAUX1/LAXs and most of the long-distance CpPINs genes increases as the somatic embryogenesis process develops in C. papaya cv. "Red Maradol". J Plant Growth Regul 36:1-15.

FRIDBORG G, PEDERSÉN M AND LANDSTROM LE. 1978. The effect of activated charcoal on tissue cultures: adsorption of metabolites inhibiting morphogenesis. Physiol Plantarum 43: 104-106.

GARCIA R, PACHECO G, FALCÃO E, BORGES G AND MANSUR E. 2011. Influence of type of explant, plant growth regulators, salt composition of basal medium, and light on callogenesis and regeneration in Passiflora suberosa L. (Passifloraceae). Plant Cell Tiss Org Cult 106: 47-54.

GUERRA MP, TORRES AC AND TEIXEIRA JB. 1999. Embriogênese somática e sementes sintéticas. In: Torres AC, Caldas LS and Buso JA (Eds), Cultura de tecidos e transformação genética de plantas. Embrapa-CBAB. 2: 533-568.

HERINGER AS, VALE EM, BARROSO T, SANTACATARINA C AND SILVEIRA V. 2013. Polyethylene glycol effects on somatic embryogenesis oh papaya hybrid 
UENF/CALIMAN 01 seeds. Theor Exp Plant Physiol 2: 116-124.

HUNDERTMARK M AND HINCHA DK. 2008. LEA (Late Embryogenesis Abundant) proteins and their encoding genes in Arabidopsis thaliana. BioMed Cent Genomics 9: 1-22.

IKEDA-IWAI M, SATOH S AND KAMADA H. 2002. Establishment of a reproducible tissue culture system for the induction of Arabidopsis somatic embryos. J Exp Bot 53: $1575-1580$.

JU H, JEYAKUMAR J, KAMARAJ M, PRAVEEN N, CHUNG I, KIM S AND THIRUVENGADAM M. 2014. High frequency somatic embryogenesis and plant regeneration from hypocotyl and leaf explants of gherkin (Cucumis anguria L.). Sci Hortic-Amsterdam 169: 161168.

KERMODE AR. 2005. Role of abscisic acid in seed dormancy. J Plant Growth Regul 24: 319-344.

KOEHLER AD, CARVALHO CA, ABREU IS AND CLARINDO WR. 2013. Somatic embryogenesis from leaf explants of hermaphrodite Carica papaya: A new approach for clonal propagation. Afr J Biotechnol 12: 2386-2391.

KRASSIMIRA S AND ALEXANDROVA BV. 2002. Isolation of two somatic embryogenesis related genes from orchardgrass (Dactylis glomerata). Plant Sci 62: 301-307.

KUMARAVELM, UMAS, BACKIYARAN S, SARASWATHI MS, VAGANAN MM, MUTHUSAMY M AND SAJITH KP. 2017. Differential proteome analysis during early somatic embryogenesis in Musa spp. AAA cv. Grand Naine. Plant Cell Rep 36: 163-178.

LAGACÉ M AND MATTON DP. 2004. Characterization of a WRKY transcription factor expressed in late torpedo-stage embryos of Solanum chacoense. Planta 219: 185-189.

LIM CW, BAEK W, JUNG J, KIM J-H AND LEE SC. 2015. Function of ABA in stomatal defense against biotic and drought stresses. Int J Mol Sci 16: 15251-15270.

LOSCHIAVO F, PITTO L, COZZANI F, VALLONE D AND TERZI M. 1991. Modulation of auxin binding proteins in cell suspensions proteins in cell suspensions. I. Differential responses of carrot embryo cultures. Plant Physiol 97: 6064.

MÁRQUEZ-LÓPEZ RE, PÉREZ-HERNÁNDEZ C, KUGONZÁLEZ Á, GALAZ-ÁVALOS RM AND LOYOLAVARGAS VM. 2018. Localization and transport of indole3 -acetic acid during somatic embryogenesis in Coffea canefora. Protoplasma 255: 695-708.

MÁRQUEZ-MARTÍN B， GUZMÁN-GARCÍA E, BARCELÓ-MUNOZA A, PLIEGO-ALFARO F AND SÁNCHEZ-ROMERO C. 2009. Effects of an in vitro maturation treatment on plant recovery from avocado zygotic embryos. Sci Hortic 122: 532-539.

MARTÍNEZ MT, VIEITEZ AM AND CORREDOIRA E. 2015. Improved secondary embryo production in Quercus alba and $Q$. rubra by activated charcoal, silver thiosulphate and sucrose: influence of embryogenic explant used for subculture. Plant Cell Tiss Org Cult 121: 531-546.

MIROSHNICHENKO DN, FILIPPOV MV AND DOLGOVA SV. 2013. Medium optimization for efficient somatic embryogenesis and in vitro plant regeneration of spring common wheat varieties. Rus Agri Sci 39: 24-28.

MOON HK, LEE H, PAEK KY AND PARK SY. 2015. Osmotic stress and strong 2,4-D shock stimulate somaticto-embryogenic transition in Kalopanax septemlobus (Thunb.) Koidz. Acta Physiol Plant 37:1710.

MURASHIGE TM AND SKOOG F. 1962. A revised medium for rapid growth and bioassays with tobacco tissue cultures. Physiol Plant 15: 473-497.

NEGIN B AND MOSHELION M. 2016. The evolution of role of ABA in regulation of water-user efficiency: From biochemical mechanisms to stomatal conductance. Plant Sci 251: 82-89.

NOLAN KE, SONG Y, LIAE S, SAEED NA, ZHANG X AND ROSE RJ. 2014. An unusual abscisic acid and gibberellic acid synergism increases somatic embryogenesis, facilitates its genetic analysis and improves transformation in Medicago truncatula. Plos One 9: e99908.

NUÑO-AYALA A，RODRÍGUEZ-GARAY B AND GUTIÉRREZ-MORA A. 2012. Somatic embryogenesis in Jarilla heterophylla (Caricaceae). Plant Cell Tiss Org Cult 109: 33-39.

OLIVEIRA EJ, KOEHLER AD, ROCHA DI, VIEIRA LM, PINHEIRO MVM, MATOS EM, CRUZ ACF, SILVA TCR, TANAKA FAO AND NOGUEIRA FTS. 2017. Morpho-histological, histochemical, and molecular evidences related to cellular reprogramming during somatic embryogenesis of the model grass Brachypodium distachyon. Protoplasma 254: 2017-2034.

PACHECO AC, CASTRO PRC AND SOUZA GM. 2011. Deficiência hídrica e aplicação de ABA nas trocas gasosas e no acúmulo de flavonoides em calêndula (Calendula officinalis L.). Acta Sci-Agro 33: 275-281.

PAN L-J AND JIANG L. 2015. Identification and expression of the WRKY transcription factors of Carica papaya in response to abiotic and biotic stresses. Mol Biol Rep 41: $1215-1225$

PARK J, LEE Y, MARTINOIA E AND GEISLER M. 2017. Plant hormone transporters: what we know and what we would like to know. BMC Biol 15: 1-15.

PLIEGO-ALFARO F, MONSALUD MJR, LITZ RE, GRAY DJ AND MOON PA. 1996. Effect of abscisic acid, osmolarity and partial desiccation on the development of recalcitrant mango somatic embryos. Plant Cell Tiss Org Cult 44: 63-70

POSADA-PÉREZ L, MONTESINOS YP, GUERRA DG, DANIELS D AND GÓMEZ-KOSKY R. 2017. Complete germination of papaya (Carica papaya L. cv. 'Maradol 
Roja') somatic embryos using temporary immersion system type RITA $^{\circledR}$ and phloroglucinol in semi-solid culture medium. In Vitro Cell Dev-P1 53: 505-513.

PULLMAN GS, GUPTA PK, TIMMIS R, CARPENTER C, KREITINGER M AND ANDWELTY E. 2005. Improved Norway spruce somatic embryo development through the use of abscisic acid combined with activated carbon. Plant Cell Rep 24: 271-279.

ROCHA DI, VIEIRA LM, TANAKA FAO, SILVA LC AND OTONI WC. 2012. Somatic embryogenesis of a wild passion fruit species Passiflora cincinnata Masters: histocytological and histochemical evidences. Protoplasma 249:747-758

SCHMILDT O, SCHMILDT ER AND AMARAL JAT. 2007. Cinetina e ANA na multiplicação in vitro de mamoeiro 'Tainung 01'. Sci Agr 8: 55-60.

SCOTT AJ AND KNOTT M. 1974. A cluster analysis method for grouping means in the analysis of variance. Biometrics 30: 507-512.

S E N T H I L K U M A R S, K U M A R N, SOORRIANATHASUNDARAM SK AND KUMAR PJ. 2014. Aspects on asexual propagation in papaya (Carica papaya L.) - a review. Agr Rev 35: 307-313.

STASZAK AM, GUZICKA M AND PAWLOWSKI TA. 2017. Signalling regulators of abscisic and gibberellic acid pathways are involved in dormancy breaking of Norway maple (Acer platanoides L.) seeds. Acta Physiol Plant 39: $1-10$.

SUN D-Q, LU X-H, LIANG G-L, GUO Q-G, MO Y-W AND XIE J-H. 2011. Production of triploid plants of papaya by endosperm culture. Plant Cell Tiss Org Cult 104: 23-29.
VALE EM, HERINGER AS, BARROSO T, FERREIRA ATS, COSTA MN, PERALES JEA, SANTA-CATARINA C AND SILVEIRA V. 2014. Comparative proteomic analysis of somatic embryo maturation in Carica papaya L. Proteome Sci 12: 1-17.

VERMA SK, DAS AK, CINGOZ GS, USLU E AND GUREL E. 2016. Influence of nutrient media on callus induction, somatic embryogenesis and regeneration in selected Turkish crocus species. Biotechnol Rep 10: 66-74.

WU K, ZENG S, CHEN Z AND DUAN J. 2012. In vitro mass propagation of hermaphroditic Carica papaya cv. Meizhonghong. Pak J Bot 44: 1669-1676.

YOSHIDA T, FUJITA Y, MARUYAMA K, MOGAMI J, TODAKA D, SHINOZAKI K AND YAMAGUCHISHINOZAKI K. 2015. Four arabidopsis AREB/ABF transcription factors function predominantly in gene expression downstream of SnRK2 kinases in abscisic acid signalling in response to osmotic stress. Plant Cell Environ 38: $35-49$.

YUMBLA-ORBES M, CRUZ ACF, PINHEIRO MVM, ROCHA DI, BATISTA DS, KOEHLER AD, BARBOSA JG AND OTONI WC. 2017. Somatic embryogenesis and de novo shoot organogenesis can be alternatively induced by reactivating pericycle cells in lisianthus (Eustoma grandiflorum (Raf.) Shinners) root explants. In Vitro Cell Dev-P1 53: 209-218.

ZIMMERMAN JL. 1993. Somatic embryogenesis: a model for early development in higher plants. Plant Cell 5: 14111423. 